\title{
Selected Techniques for Monitoring Water Movement Through Unsaturated Alluvium During Managed Aquifer Recharge
}

\section{By Joseph M. Nawikas, David R. O'Leary, John A. Izbicki, and Matthew K. Burgess}

Managed aquifer recharge is used to augment natural recharge to aquifers. It can be used to replenish aquifers depleted by pumping or to store water during wetter years for withdrawal during drier years. Infiltration from ponds is a commonly used, inexpensive approach for managed aquifer recharge.

At some managed aquiferrecharge sites, the time when infiltrated water arrives at the water table is not always clearly shown by water-level data (fig. 1). As part of site characterization and operation, it can be desirable to track downward movement of infiltrated water through the unsaturated zone to identify when it arrives at the water table.
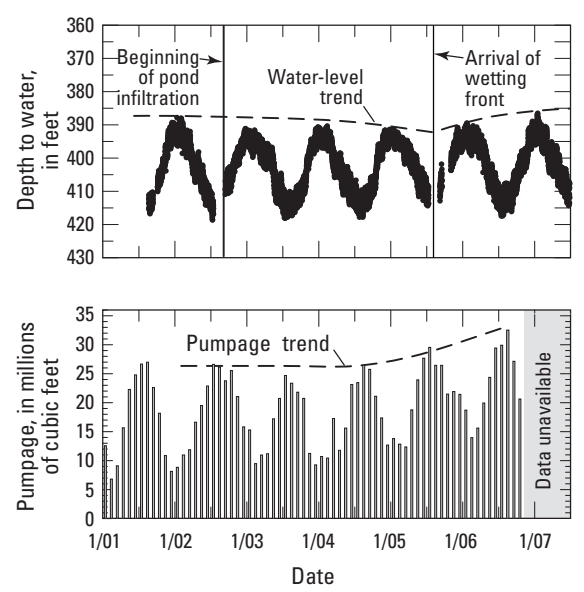

Figure 1. Water-level and pumping data from a managed aquifer-recharge site near Victorville, California, 2001-07. The data show water-level changes caused by nearby pumping that can make it difficult to identify when infiltrated water arrives at the water table (Izbicki and others, 2008).

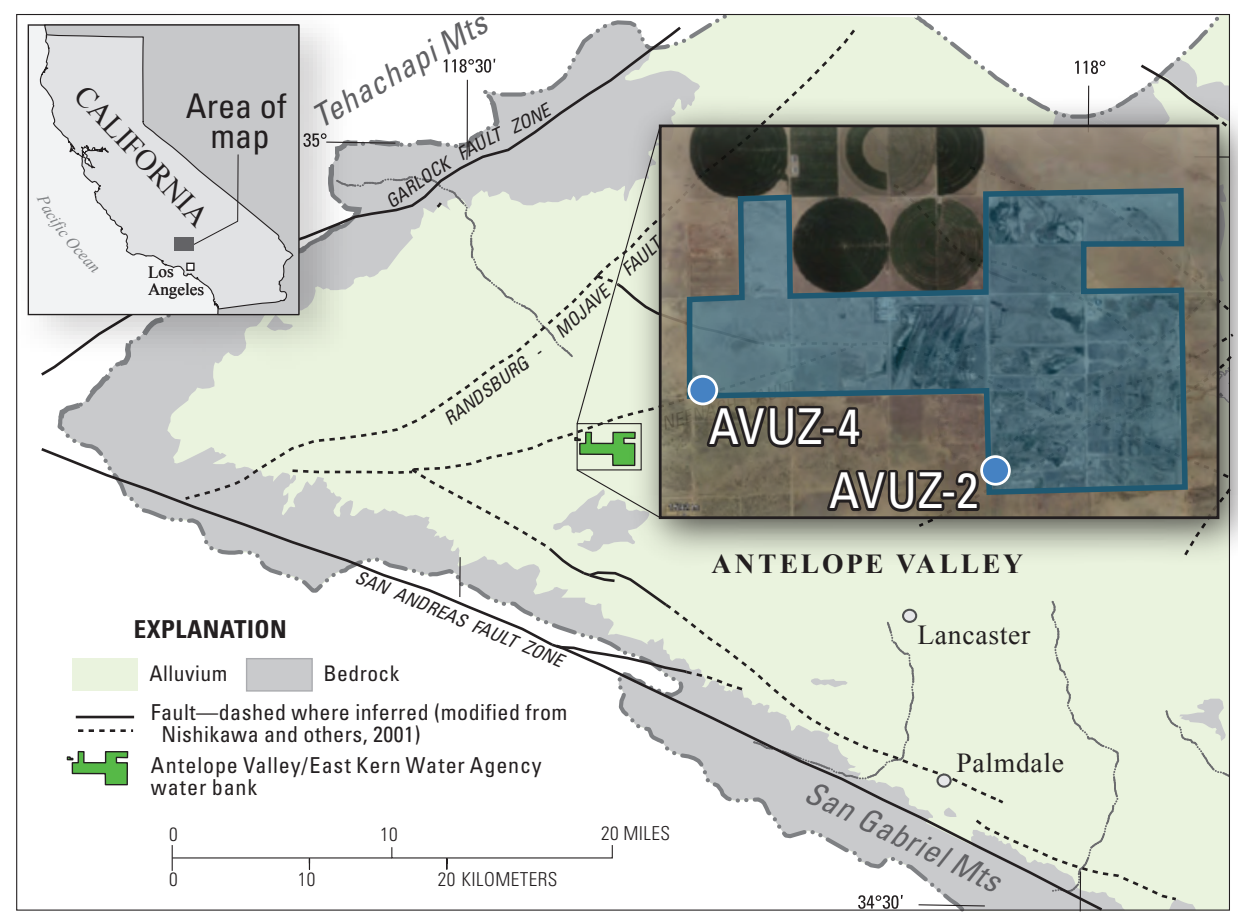

Figure 2. Experimental field-scale recharge sites at the Water Supply Stabilization Project-2 site, Antelope Valley, California. The AVUZ-2 and AVUZ-4 test sites include recharge ponds and instrumentation for monitoring the downward movement of water infiltrated from the pond.

\section{The Water Supply Stabilization Project-2 Site}

Antelope Valley East Kern Water Agency (AVEK) has developed a managed aquifer recharge and recovery program known as the Water Supply Stabilization Project (WSSP-2). The project area is on about 2.3 square miles of former agricultural land in the Antelope Valley groundwater subbasin (California Department of Water Resources, 2003), about 53 miles north of Los Angeles (fig. 2). Alluvial fan deposits underlying the project area consist of interbedded, heterogeneous mixtures of poorly sorted gravels, sands, silts, and clays. The climate of the area is arid and characterized by cold winters and hot, dry summers.

The WSSP-2 project area is to be operated as a water bank to recharge and store water imported from northern California during wetter years for use during drier years. AVEK and the Los Angeles Department of Public Works, in cooperation with the U.S. Geological Survey (USGS), constructed several test sites in the project area to evaluate its suitability for groundwater recharge from ponds before full-scale development of the WSSP-2 project area. Each test site is within 50 feet ( $\mathrm{ft}$ ) of a recharge area.

Using selected preliminary results from the WSSP-2 test site, this report describes the techniques available through the USGS California Water Science Center for monitoring the downward and lateral movement of water, including test drilling and installation of instrumented boreholes, sequential electromagnetic induction logging (EMresistivity), surface direct-current (DC) resistivity, borehole DC resistivity, and distributed temperature sensing (DTS). Additional techniques, such as sequential gravity measuring, are available but not detailed in this report. Each of these techniques can be used independently or can be combined with any other of these techniques for a more robust interpretation of water movement through unsaturated alluvium. 


\section{Instrumented Boreholes}

Instrumented boreholes installed by using the ODEX $^{1}$ (Overburden Drilling Exploration) drilling technique (Hammermeister and others, 1986; Izbicki and others, 2000) are used to monitor movement of water through the unsaturated zone. Unlike conventional drilling methods, ODEX uses air as a drilling fluid rather than water. The water in conventional drilling mud can alter the water content and matric potential of unsaturated materials during drilling.
The ODEX boreholes are stabilized by advancing an 8.7-inchdiameter steel casing behind an eccentric (larger diameter) drill bit. Collection of cuttings at 1-foot intervals and core material for hydraulic property analyses is coordinated with drilling. Instruments are positioned in the borehole on the basis of lithologic data, gamma and neutron geophysical logs, and the specific conductance of water extracted from cuttings (fig. 3). Sand and grout are used to backfill each borehole as the steel casing is removed.

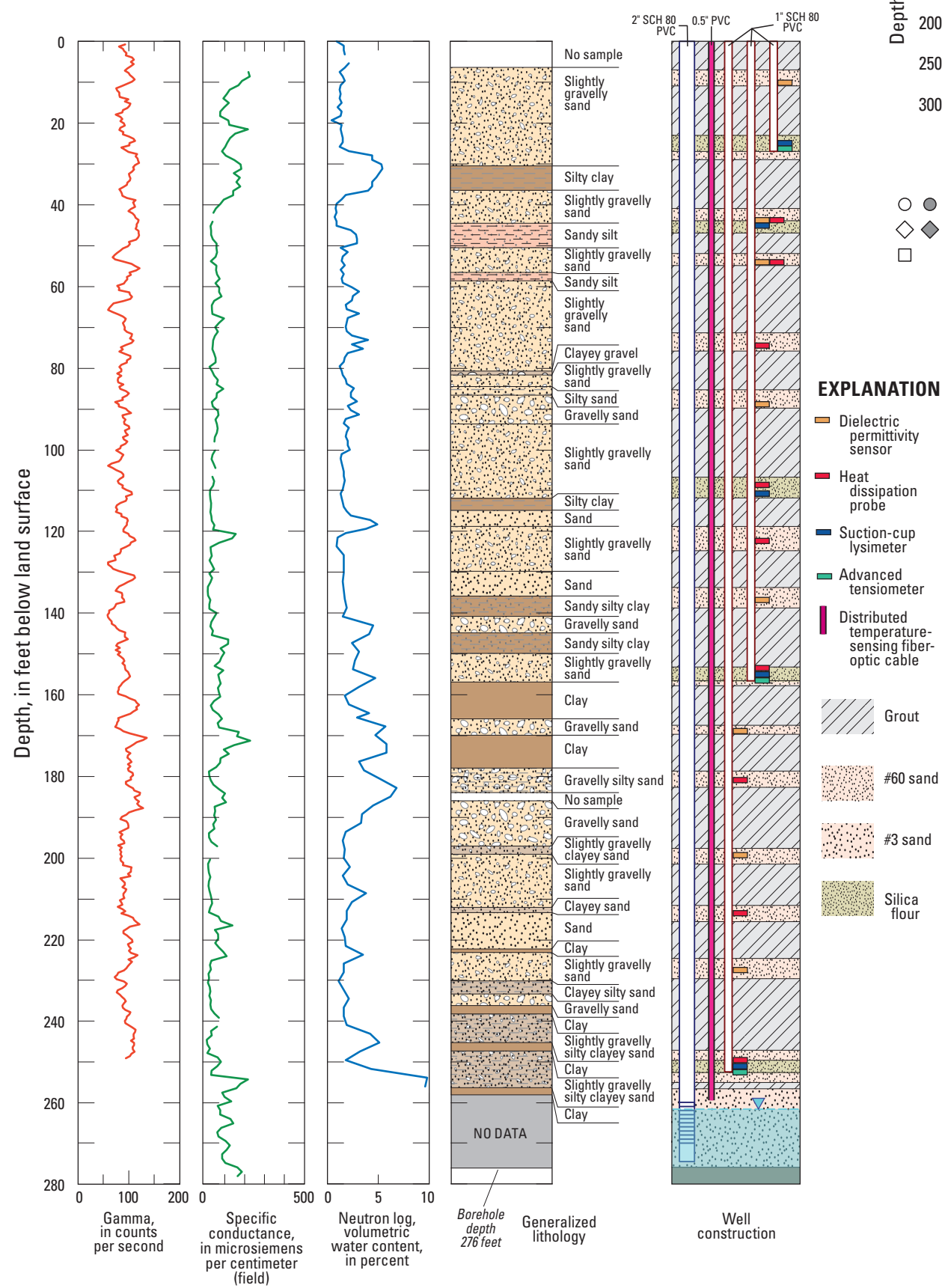

Figure 3. Selected geophysical, lithologic, and construction data from AVUZ-4 instrumented borehole, Water Supply Stabilization Project-2, Antelope Valley, California. The ODEX borehole, drilled by using air rather than water as a drilling fluid, was logged for lithology and specific conductance at 1-foot intervals; 25 instruments and a water-table well were included in the borehole (Izbicki and others, 2015).
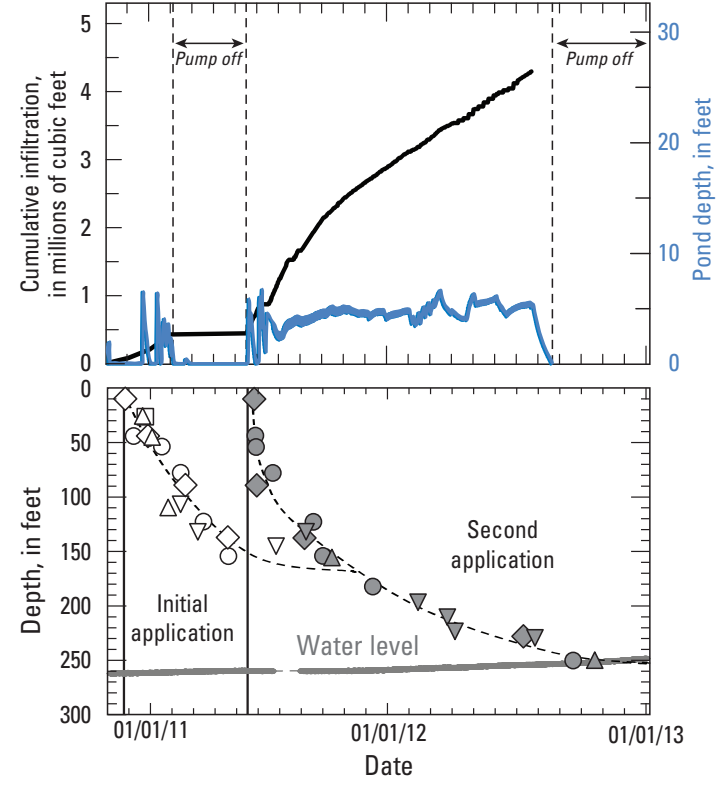

EXPLANATION

Heat-dissipation probe $\triangle \triangle$ Suction-cup lysimeter $\diamond$ Dielectric permittivity sensor $\nabla \nabla$ Electromagnetic log Advanced tensiometer $\quad \cdots$ Inferred depth of wetting front

Figure 4. Instruments in the AVUZ-4 ODEX borehole, near the recharge pond, track the downward movement of the wetting front through the unsaturated zone by measuring changes in matric potential, Antelope Valley, California, January 1, 2011-January 1, 2013 (Izbicki and others, 2015).

In general, instrumentation includes 10 feet of well screen at the water table, matric-potential sensors, and suctioncup lysimeters to collect water samples (fig. 3). The well, which is made of 2-inchdiameter polyvinyl chloride (PVC) casing, provides access for repeated geophysical measurements. Instruments are controlled by data loggers in a vault at land surface, and data are collected and recorded at 4-hour (hr) intervals. Suction-cup lysimeters are sampled at roughly 6-week intervals.

Matric-potential data collected from borehole instruments can be used with hydraulic properties obtained from drill cuttings and cores to estimate water flux. Arrival of the wetting front is identified by increases in matric potential (less negative values) and, in some cases, by the development of perched conditions (positive pressure) measured by tensiometers (fig. 4). Arrival of the wetting front at a lysimeter is evident when they begin to yield water.

${ }^{1}$ Use of trade names in this report is for descriptive purposes only and does not constitute endorsement by the U.S. Geological Survey. 


\section{Sequential Electromagnetic Logging}

Electromagnetic resistivity is sensitive to differences in the lithology and water content of unsaturated materials. Because the lithology of a site remains constant and moisture content changes as water infiltrates through the unsaturated zone, decreases in EM resistivity through time can be used to track the wetting front as water from a pond infiltrates and moves downward through the unsaturated zone (fig. 5). Because of this, sequential EM log data are useful for monitoring the downward movement of the wetting front in boreholes that have few instruments or in boreholes that have no instruments other than a well or PVC access tube. The use of sequential EM logs collected from PVC-cased access tubes can also reduce installation time for boreholes, thereby reducing construction and site instrumentation costs.

The borehole tool used in this study measures EM resistivity within a donut-shaped torus that has an inner diameter of about 18 inches
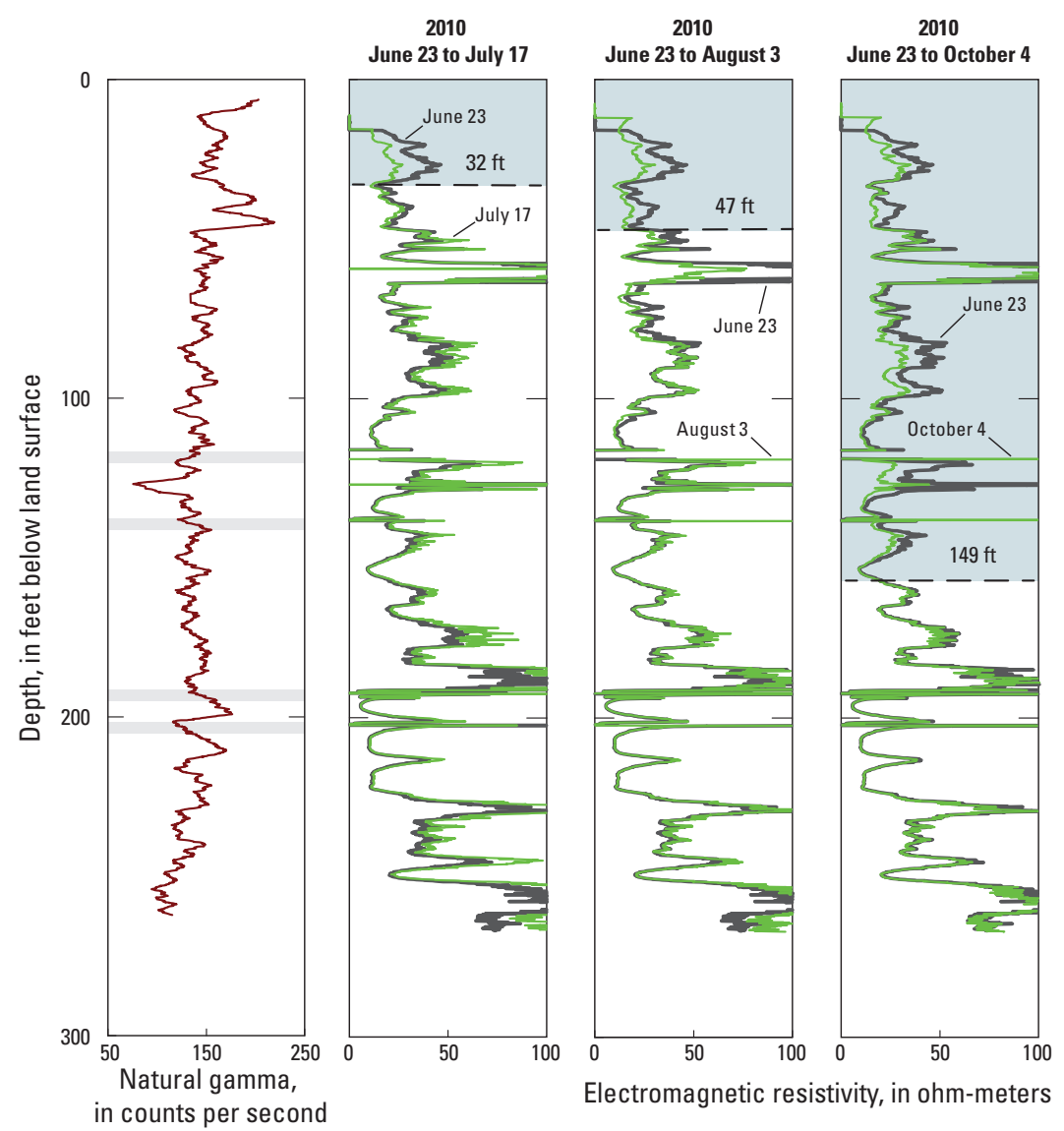

Electromagnetic resistivity, in ohm-meters
2010

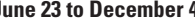

Figure 5. Changes in subsurface electrical properties at AVUZ-2, Antelope Valley, California, June 23, July 17, August 3, October 4, and December 4, 2010, were recorded by collecting sequential electromagnetic (EM) logs. Blue shaded regions and dashed lines represent the downward migration of the wetting front with time. Analogous dips and spikes in the EM resistivity, shown by using gray bands, serve as a quality control check for instrument placement. The accuracy and reproducibility of this technique make it a useful option for tracking the downward movement of infiltrated water.

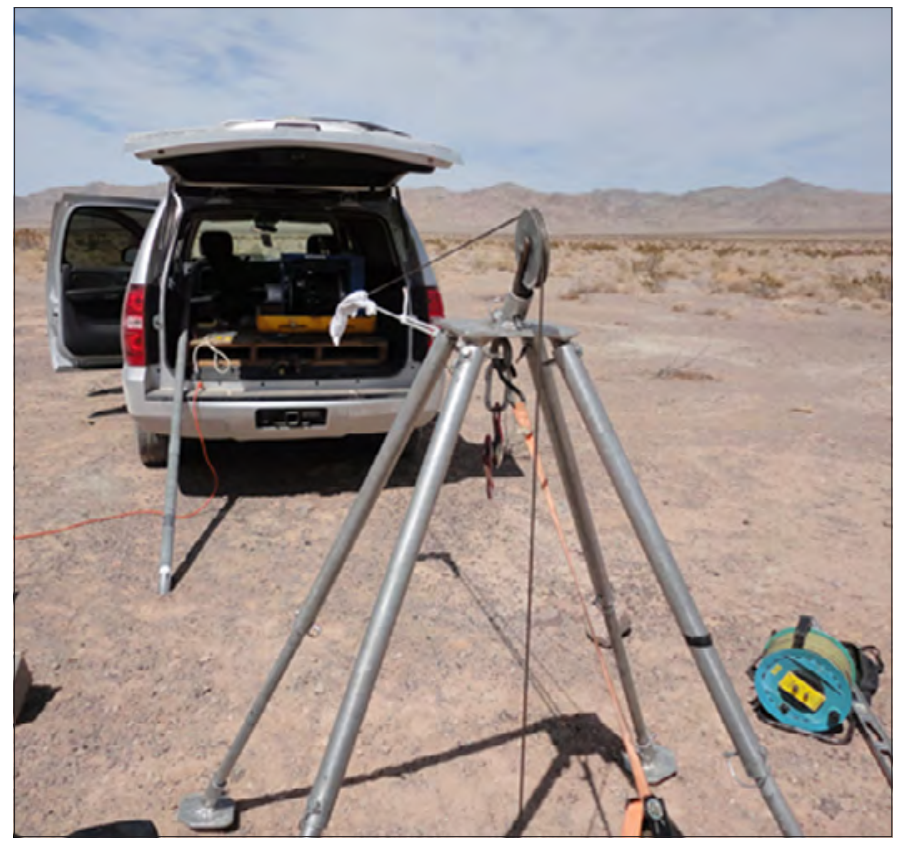

Figure 6. Typical geophysical logging configuration. The equipment is transported with and operated from a standard sport utility vehicle. The small footprint and custom quad-pod allow for data collection in a wide variety of locations. and an outer diameter of about 50 inches

(Century Geophysical Corp., 2008). As a consequence, the tool is relatively insensitive to the fill material placed in the borehole adjacent to the access tube (fig. 3). The sequential EM-logging approach is particularly useful for monitoring the downward movement of the wetting front between instruments and is similar to the approach used by Ferré and others (2007). The EM-resistivity logs are sensitive to metal in some of the instruments installed in the borehole. The characteristic response to metal (dips and spikes) in the EM-resistivity data serves as a quality-control check on the depth of instrument placement in the borehole (fig. 5).

Sequential EM-resistivity data can be collected from the PVC access tubes placed in mud-rotary drilled boreholes (fig. 6). Data from two mud-rotary drilled boreholes 25 and $50 \mathrm{ft}$ downslope from the AVUZ-2 recharge pond (not shown in fig. 5) showed lateral movement of water from the pond on the sloping clay layer, as indicated by higher gamma activity at AVUZ-2 from 33 to $51 \mathrm{ft}$ below land surface than at other depths (fig. 5).

Changes in EM resistivity also can be used to track changes in water quality in the saturated zone in intervals not screened by wells (Metzger and Izbicki, 2013). The technique can be useful for monitoring the movement of high-quality, low-dissolvedsolids water used to recharge aquifers that have poor water quality. 


\section{Surface Direct-Current Resistivity}

Direct-current resistivity measures the resistance of the ground to an electrical current (Zohdy and others, 1974). The resistance is converted to apparent resistivity by using geometric factors specific to the electrode configuration. Resistivity is determined through numerical inversion of the field data. Similar to EM resistivity, the electrical resistivity is a function of the lithology and water content of the unsaturated materials. Thus, sequential measurements of DC resistivity can be used to qualitatively map the downward and lateral movement of infiltrated water through the unsaturated zone with time (fig. 7).

To collect DC-resistivity data, electrodes attached to cables are deployed at land surface along selected transects near the recharge ponds. The configuration of transects can be adjusted for site conditions, but should remain uniform over time. The depth of penetration of the electrical current is controlled by the electrode spacing along the cables, such that shorter electrode spacing $(6.5 \mathrm{ft})$ provides greater resolution but shallower penetration, and greater electrode spacing (32.8 ft) provides less resolution but deeper penetration (fig. 8). Different electrode configurations, such as Wenner or dipole-dipole arrays (Zohdy and others, 1974), can improve resolution and data interpretation at a given site.

The DC-resistivity data can be collected at strategic times, such as before, during, and after water infiltrates from the ponds. It is necessary to accurately record initial electrode locations, allowing for precise reoccupation over time. Signal penetration and data quality can improve through time as the unsaturated zone is progressively wetted by infiltrated water and the resistance of unsaturated materials decreases. Collection of surface DC-resistivity data does not require drilling or permanently installed equipment.
A
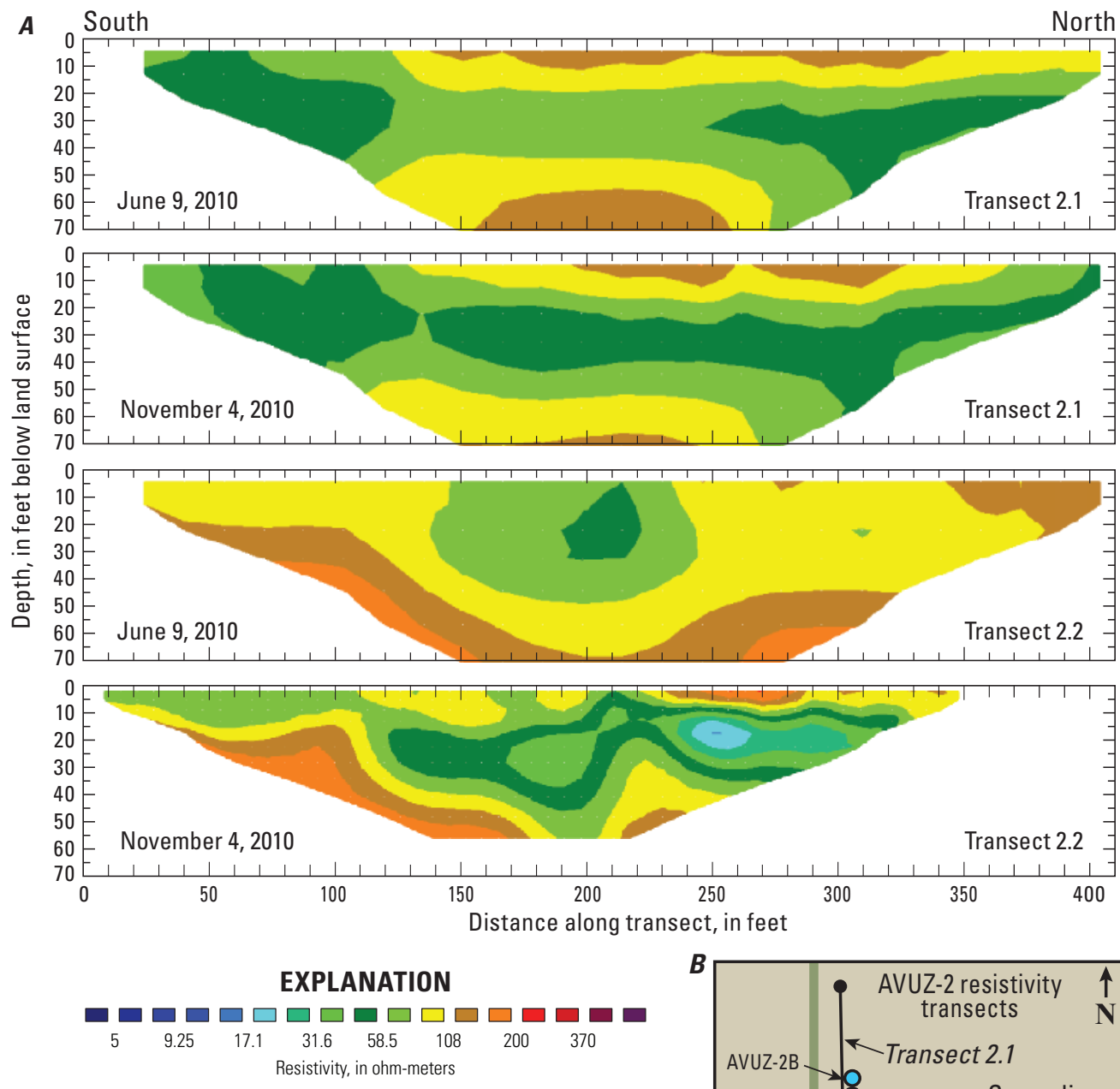

Figure 7. A, Selected direct-current-resistivity data (dipole-dipole) along transects near an infiltration pond at the $\boldsymbol{B}$, Water Supply Stabilization Project-2 site, Antelope Valley, California, June 9 and November 4, 2010. Data were collected prior to and during infiltration of water. Warmer colors show drier materials; cooler colors show wetter materials. Note the effect of a clay layer limiting the downward movement of water.
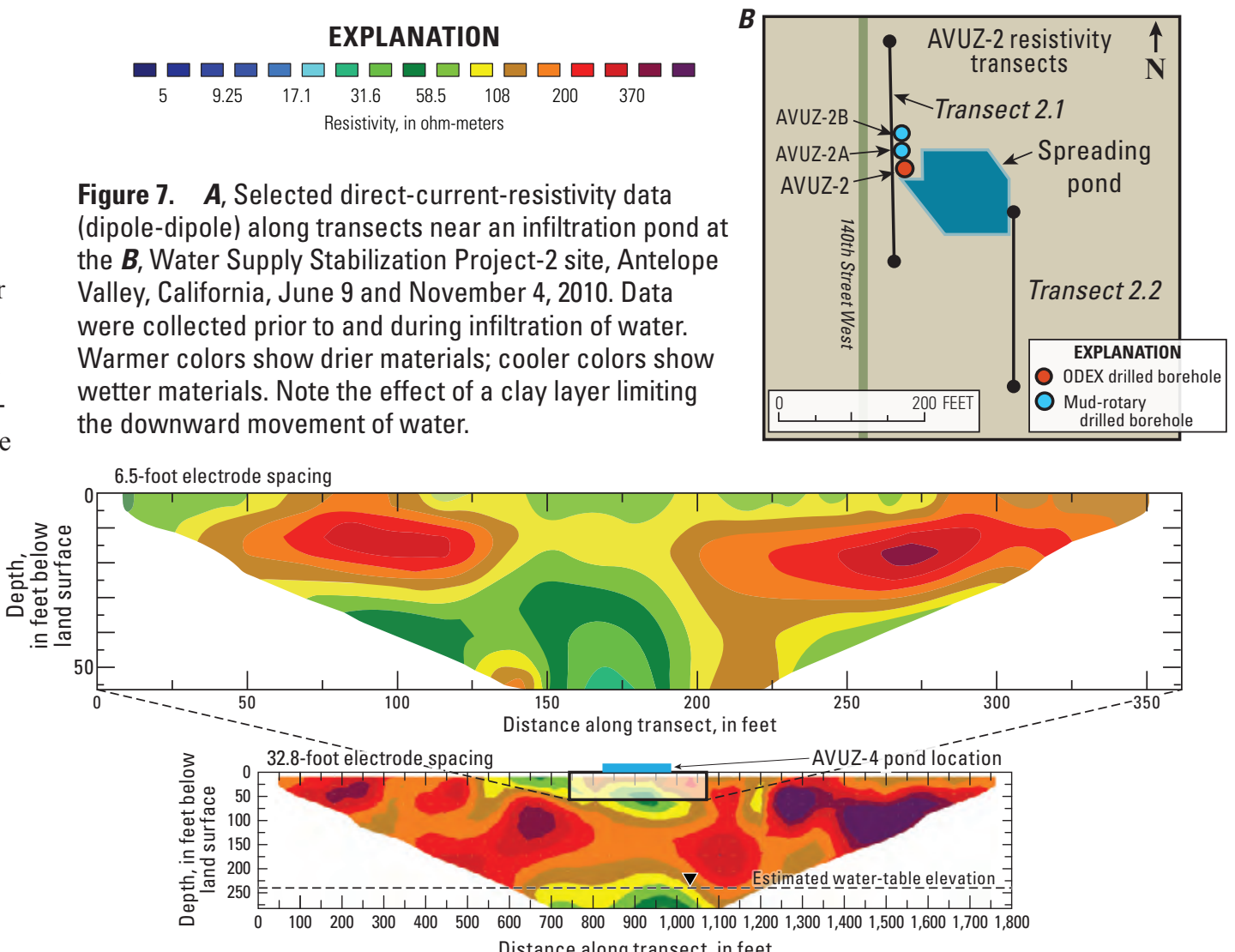

EXPLANATION

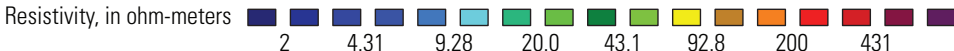

Figure 8. Direct-current-resistivity data collected near AVUZ-4 at 6.5- and 32.8-foot electrode spacing, Water Supply Stabilization Project-2, Antelope Valley, California, July 12, 2011. The data show the difference in penetration and resolution in the unsaturated zone with different electrode spacing. Warmer colors show drier materials; cooler colors show wetter material. 


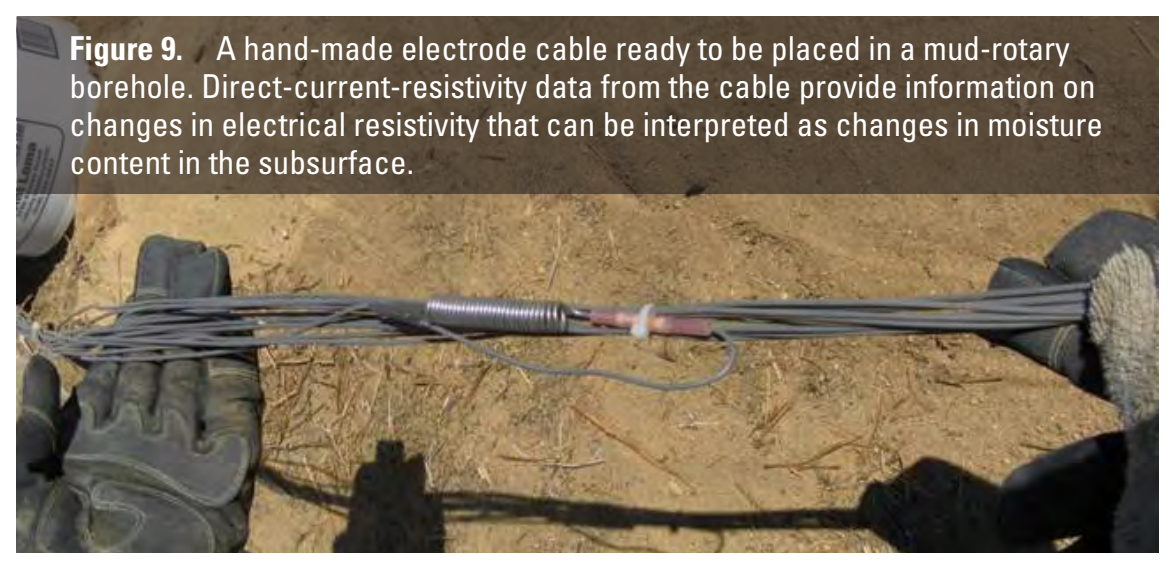

AVUZ-2A

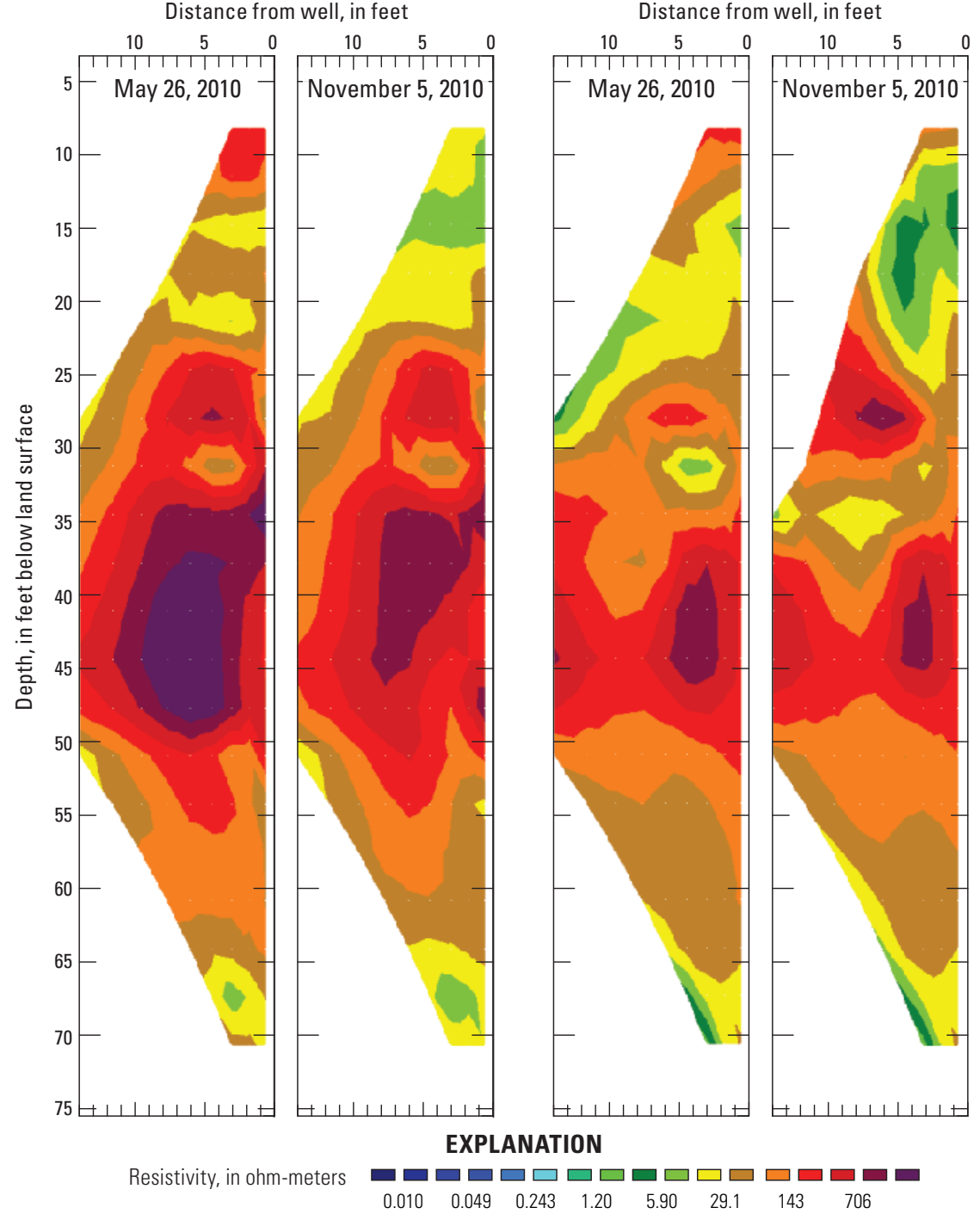

Figure 10. Direct-current (DC) resistivity data from boreholes AVUZ-2A and AVUZ-2B at the Water Supply Stabilization Project-2 site, Antelope Valley, California, May 26 and November 5, 2010. Warmer colors represent more resistive, drier materials; cooler colors represent less resistive, wetter materials. The data indicate lateral movement of water infiltrated from a nearby pond along clay layers through the subsurface. (Note: measured resistance was converted to apparent resistivity by using geometric factors specific to the electrode configuration in the same manner as surface DC resistivity. The authors recognize that there are differences between surface- and borehole-resistivity data, but relative changes between data collected at different times can reflect changes in moisture content resulting from recharge. Actual values of apparent resistivity calculated from borehole data in this manner could be in error.)

\section{Borehole Direct-Current Resistivity}

The DC-resistivity data can also be collected from boreholes in the same manner as surface DC-resistivity data are collected (Zohdy and others, 1974). Changes in the electrical resistivity of unsaturated materials through time can be interpreted as changes in water content.

The electrodes and cable are installed in hydraulic contact with the formation in either ODEX or mud-rotary drilled boreholes. The use of a mud-rotary borehole reduces installation costs; however, additional instrumentation, including matric potential sensors and suction-cup lysimeters, cannot be installed in mud-rotary boreholes. The electrodes and cable for borehole applications are available from a commercial vendor or can be hand-made (fig. 9). Shielding could be needed to ensure the cable does not interfere with the EMresistivity measurements taken from the PVC access tubes in the same borehole.

The same data-acquisition equipment used to collect surface DC-resistivity data can be used to collect data from boreholes. After the cables are installed, data can be collected by an individual with minimal training.

Borehole DC-resistivity data provide a vertical profile of electrical resistivity in the unsaturated zone (fig. 10). Although presented as a two-dimensional vertical section, these data actually represent the average resistivity of unsaturated materials in a cylindrical volume surrounding the borehole. Borehole DC-resistivity data can provide information on the downward movement of the wetting front through the subsurface next to the borehole.

Similar to the surface DC-resistivity technique, data initially collected from boreholes can be difficult to interpret. Data quality improves, however, as the unsaturated zone is wetted from infiltration. Data from several DC-resistivity boreholes placed in close proximity can provide information about the lateral movement of water through the subsurface. Borehole- and surface-resistivity data can be combined by using an approach known as tomography to provide more detailed information on water movement through the unsaturated zone. 


\section{Distributed Temperature Sensing}

Distributed temperature sensing (DTS) was used to monitor changes in temperature resulting from infiltration of water at the WSSP-2 site. Applications for DTS at surficial recharge facilities include measurement of differences in nearsurface infiltration rates and measurement of declines in surficial infiltration rates that result from physical clogging of recharge facilities. The DTS methods have been used less commonly in hydrologic studies to evaluate infiltration deeper in the unsaturated zone.

The DTS equipment uses scattering of laser light in fiber-optic cables to estimate the temperature along the cable. A DTS instrument sends pulsed light through the cable and measures backscatter. Stokes (where energy is absorbed, so the scattered photon has less energy than the incident photon) and temperature-dependent anti-Stokes (where energy is lost, so the scattered photon has more energy than the incident photon) scattering of the light occurs in the cable. The reflected light is recorded, and the frequency content is analyzed to compute temperature along the cable as a function of the time-of-flight, down and back, along the fiber-optic cable. The DTS measurement provides a continuous measure of temperature that has a thermal resolution of 0.01 degrees Fahrenheit for any location along the cable and a spatial resolution of $3 \mathrm{ft}$ (U.S. Geological Survey, 2013).

Fiber-optic cables can be installed in ODEX or mud-rotary boreholes. In the WSSP-2 project area, fiber-optic cables were installed in three boreholes at the AVUZ-2 site along a cross-section leading away from the recharge pond. The DTS measurements were collected from fiberoptic cables at 4-hr intervals for 6 months.
The data showed daily temperature variations penetrating to depths of approximately $9 \mathrm{ft}$ into the subsurface (fig. 11). The magnitude of the daily variations is dampened at AVUZ-2 next to the pond and is dampened as the wetting front moves downward and laterally because of the high specific heat of water. The temperatures recorded are a function both of convective and advective movement of thermal energy associated with the wetting front and the thermal properties of unsaturated-zone material; both should be taken into account when tracking the movement of water. Additionally, a reference site unaffected by recharge water is useful for interpreting temperature data and the movement of recharge water, especially with respect to daily and seasonal temperature variations. Numerical models, such as computer code VS2DH (Healy, 1996), also are commonly used to interpret temperature data to estimate the hydraulic properties of the unsaturated zone and water fluxes.
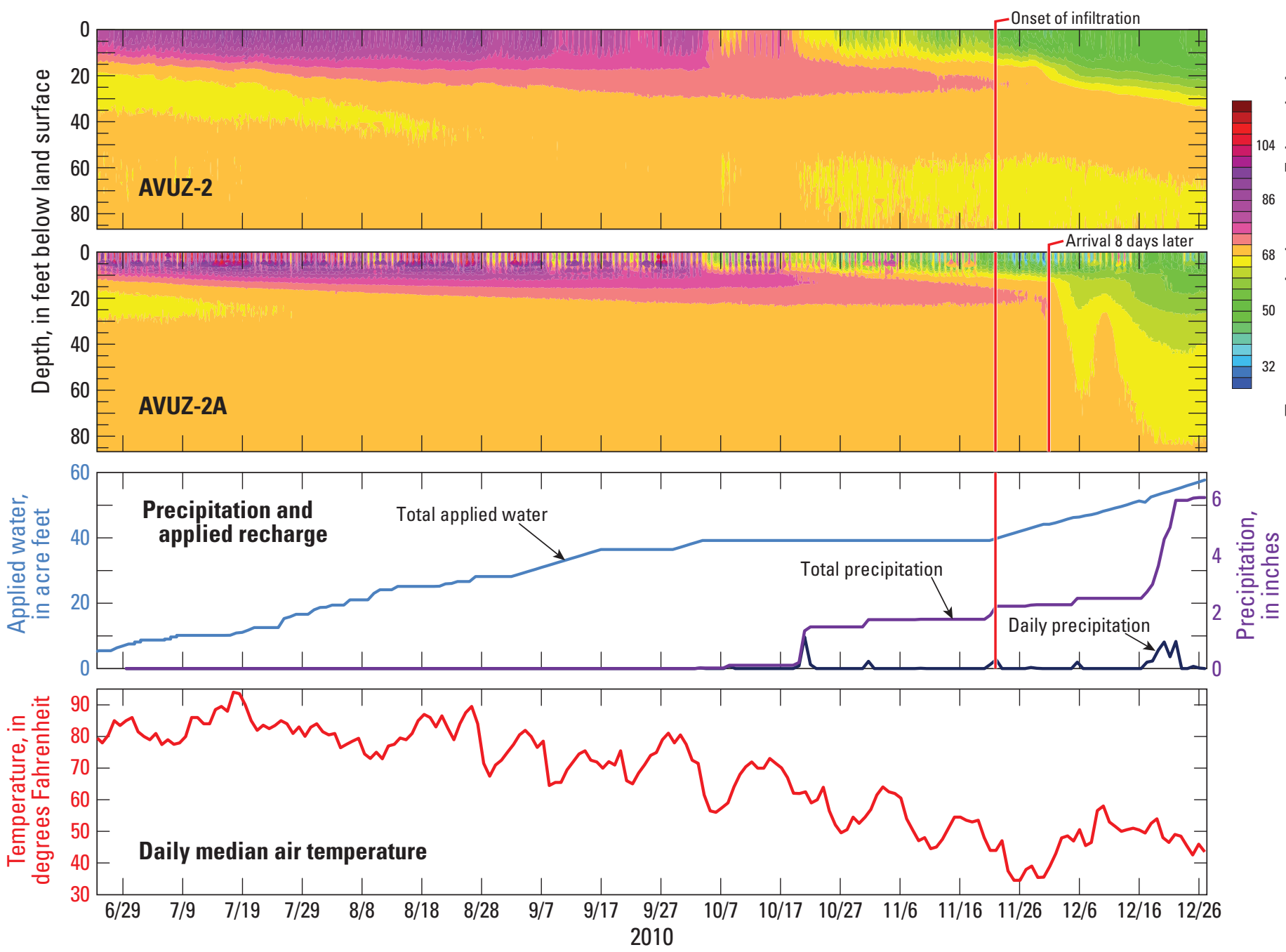

Figure 11. Temperature data from boreholes drilled next to - and 25 feet away from-the AVUZ-2 infiltration pond at the Water Supply Stabilization Project-2 site, Antelope Valley, California, June 24, 2010-December 27, 2010. Following the onset of infiltration, the data show changes in temperature in the unsaturated zone at the ODEX drilled AVUZ-2 borehole next to the pond. Upon arrival of infiltrated water eight days later, similar changes are observed in the mud-rotary drilled AVUZ-2A borehole, 25 feet away from the pond.The data indicate a lateral velocity of 3.1 feet per day from the pond. Data for total applied recharge provided by Antelope Valley-East Kern Water Agency. Precipitation and air temperature data from National Weather Service GHCND: USW00003159 Lancaster William J Fox field CA US. 


\section{Conclusions}

The techniques described are used to collect information about the vertical and lateral movement through the unsaturated zone of water infiltrated from ponds as part of managed aquifer-recharge projects. Each technique has benefits and limitations with respect to (1) temporal, spatial, and vertical data resolution; (2) ease of collection, including the need for specialized drilling, equipment, or highly-trained personnel; and (3) the degree to which data can be qualitatively and quantitatively interpreted. Although costs differ greatly depending on site-specific characteristics and management goals, some generalizations can be made about how the cost of these techniques can differ (table 1).

An instrumented borehole that has as many as 25 matric potential or other instruments installed by using ODEX drilling or other specialized drilling techniques can provide detailed quantitative information on unsaturated-zone geology, hydrology, and water movement at one specific location. Depending on the thickness of the unsaturated zone and the number of instruments, fully instrumented boreholes can require more than a week to drill and construct and are correspondingly expensive. Information from more than one fully instrumented borehole as part of a single managed aquifer recharge program could be cost prohibitive. In contrast to fully instrumented ODEX boreholes, two mudrotary boreholes can be drilled to a depth of $100 \mathrm{ft}$ and instrumented with access tubes for sequential EM measurements, cables for borehole DC resistivity, or fiber-optic cables for DTS measurements in about a day. Techniques that do not require drilling, such as DC resistivity, can provide the most inexpensive data. Interpretation of DC-resistivity data can be difficult, however, unless constrained by some type of geologic data.

Once installed, the instrumented ODEX or mud-rotary boreholes can be maintained through periodic site visits or transmitted in real time. Interpretation of matric potential sensor, EM-resistivity log, and surface- or borehole-resistivity data often depends on an initially large contrast in physical or electrical properties in the unsaturated zone. This contrast can diminish after the unsaturated zone has been wetted by infiltrating water, making continued monitoring of infiltration at a site difficult. Contrasts in temperature on a daily or seasonal basis can allow continued monitoring of infiltrated water for real-time operation of sites. Similar to matric potential data from instrumented boreholes, DTS instruments also are able to transmit data in real time. For DC-resistivity and DTS techniques, acquisition and interpretation of data by trained personnel using specialized equipment and software is needed.

Measurement of pond infiltration rates and volumes and water levels do not always provide all the information needed to characterize suitability of sites for managed aquifer recharge from ponds. Fortunately, an array of tools is available to water managers for use in monitoring managed artificial-recharge programs. Each of the techniques presented in this paper can be used individually, but the techniques work better when two or more are used in combination to confirm and verify interpretations of water movement through unsaturated alluvium.

Table 1. Generalized costs for measurement of the movement of water through a thick unsaturated zone.

[EM, electromagnetic; DC, direct current (electrical); DTS, distributed temperature sensing; ODEX, Overburden Drilling Exploration; X, applicable; - , not applicable]

\begin{tabular}{|c|c|c|c|c|c|c|}
\hline \multirow[b]{2}{*}{ Category } & \multicolumn{2}{|c|}{ Drilling technique } & \multirow{2}{*}{$\begin{array}{c}\text { No } \\
\text { borehole } \\
\text { required }\end{array}$} & \multirow[b]{2}{*}{$\begin{array}{c}\text { Lateral } \\
\text { data }\end{array}$} & \multicolumn{2}{|c|}{ Cost } \\
\hline & ODEX & Mud rotary & & & Installation & $\begin{array}{l}\text { Maintenance } \\
\text { and } \\
\text { interpretation }\end{array}$ \\
\hline Instrumented boreholes & - & - & - & ${ }^{1} \mathrm{X}$ & $\$ \$ \$ \$$ & $\$$ \\
\hline Matric potential sensors ${ }^{2}$ & $\mathrm{X}$ & - & - & - & - & - \\
\hline Water-table well ${ }^{2}$ & $\mathrm{X}$ & $X$ & - & - & - & - \\
\hline Suction-cup lysimeters ${ }^{2}$ & $\mathrm{X}$ & - & - & - & - & - \\
\hline Saturated-zone well ${ }^{2}$ & $\mathrm{X}$ & $\mathrm{X}$ & - & - & - & - \\
\hline Sequential EM logging & $\mathrm{X}$ & $\mathrm{X}$ & - & ${ }^{1} \mathrm{X}$ & $\$ \$$ & $\$ \$$ \\
\hline Surface DC resistivity & - & - & $\mathrm{X}$ & $\mathrm{X}$ & $\$$ & $\$ \$ \$$ \\
\hline Borehole DC resistivity & $\mathrm{X}$ & $\mathrm{X}$ & - & ${ }^{1} \mathrm{X}$ & $\$ \$$ & $\$ \$$ \\
\hline DTS fiber optics & $\mathrm{X}$ & $\mathrm{X}$ & - & ${ }^{1} \mathrm{X}$ & $\$ \$$ & $\$ \$ \$$ \\
\hline
\end{tabular}

${ }^{1}$ Lateral data can be collected by using multiple boreholes.

${ }^{2}$ Costs of individual instrumentation are not unique and are outlined to demonstrate capabilities of specific borehole types. 


\section{References Cited}

California Department of Water Resources, 2003, California's groundwater update 2003: California Department of Water Resources Bulletin 118, 246 p. accessed September 24, 2014, at www.water.ca.gov/pubs/groundwater/ bulletin_118/basindescriptions/6-44.pdf.

Century Geophysical Corp., 2008, User guide, slim hole induction tool model numbers 9510, 9511, and 9512: Tulsa, Okla., accessed February 15, 2008, at www.century-geo.info/dnn/EquipmentSales/ LoggingTools/9512LoggingTool.aspx.

Ferré, T.P.A., Binley, A.M., Blasch, K.W., Callegary, J.B., Crawford, S.M., Fink, J.B., Flint, A.L., Flint, L.E., Hoffmann, J.P., Izbicki, J.A., Levitt, M.T., Pool, D.R., and Scanlon, B.R., 2007, Geophysical methods for investigating ground-water recharge: Appendix 2 in Stonestrom, D.A., Constantz, J., Ferre, T.P.A., and Leake, S.A., eds., Ground-Water Recharge in the Arid and Semiarid Southwestern United States: U.S. Geological Survey Professional Paper 1703, p. 377-415, http://pubs.usgs.gov/pp/ pp1703/app2\%.

Hammermeister, D.P., Blout, D.O., and McDaniel, J.C., 1986, Drilling and coring methods that minimize the disturbance of cuttings, core, and rock formations in the unsaturated zone, Yucca Mountain, Nevada, in Proceedings of the National Water Well Association Conference on Characterization and Monitoring of the Vadose (Unsaturated) Zone: Worthington, Ohio, National Water Well Association, p. 507-514.
Healy, R.W., and Ronan, A.D., 1996, Documentation of computer program VS2DH for simulation of energy transport in variably saturated porous media-Modification of the U.S. Geological Survey's computer program VS2DT: U.S. Geological Survey Water-Resources Investigations Report 96-4230, 36 p., http://pubs.usgs.gov/ wri/1996/4230/report.pdf.

Izbicki, J.A., Clark, D.A., Pimentel, M.I., Land, M., Radyk, J., and Michel, R.L., 2000, Data from a thick unsaturated zone underlying Oro Grande and Sheep Creek washes in the western part of the Mojave Desert, near Victorville, San Bernardino County, California. U.S. Geological Survey Open-File Report 00-262, 133 p., http:// pubs.usgs.gov/of/2000/0262/report.pdf.

Izbicki, J.A., Flint, A.L., and Stamos, C.L., 2008, Artificial recharge through a thick, heterogeneous unsaturated zone: Groundwater, v. 46, no. 3, p. 475-488, http://pubs. er.usgs.gov/publication/70032008.

Izbicki, J.A., O’Leary, D.R., Burgess, M.K., Kulp, T., Surrez, D., Barnes, T., Ajwani, C., and Kim, T.J., 2015, In situ arsenic removal during groundwater recharge through unsaturated alluvium: Denver, Colo., Water Research Foundation, 34 p., http://ca.water. usgs.gov/pubs/2015/IzbickiEtAl2015-2.pdf.

Metzger, L.F., and Izbicki, J.A., 2013, Electromagnetic-induction logging to monitor changing chloride concentrations: Groundwater, v. 51, no. 1, p. 108-121, http://pubs. er.usgs.gov/publication/70095242.
Nishikawa, Tracy, Rewis, D.L., and Martin, Peter Martin, 2001, Numerical simulation of ground-water flow and land subsidence at Edwards Air Force Base, Antelope Valley, California: U.S. Geological Survey Water-Resources Investigations Report 01-4038, 111 p., http://pubs.usgs.gov/ wri/2001/4038/pdf/wri014038.pdf.

U.S. Geological Survey, 2013, Fiber-optic distributed temperature sensing technology demonstration and evaluation project, accessed September 30, 2014, at http:// water.usgs.gov/ogw/bgas/fiber-optics/.

Zohdy, A.A.R., Eaton, G.P., and Mabey, D.R., 1974, Application of surface geophysics to groundwater investigations: Techniques of Water-Resources Investigations of the U.S. Geological Survey, book 2, chap. D1, 66 p., http://pubs.usgs.gov/twri/twri2-d1/pdf/ TWRI_2-D1.pdf.

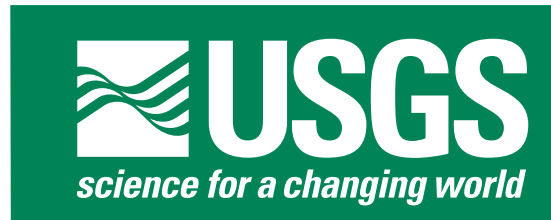

For additional information on this report contact

Joseph Nawikas

4165 Spruance Road, Suite 200

San Diego, CA 92101

(619) 225-6148

e-mail: jnawika@usgs.gov

Test infiltration pond by wells AVUZ-2, -2A and -2B at WSSP-2 site, Antelope Valley, Calfornia.

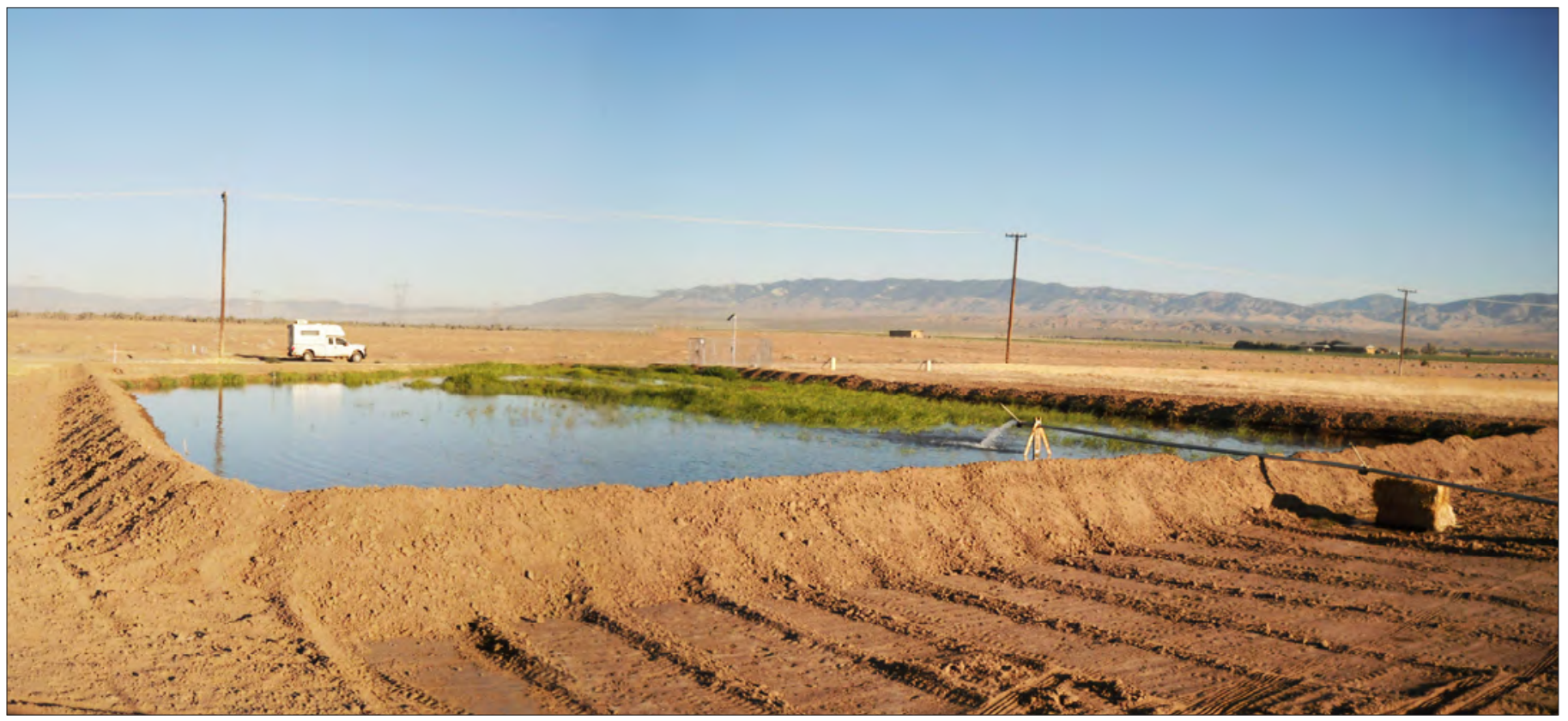

